\title{
TRENDS IN STUDIES ON VIRTUAL LEARNING ENVIRONMENTS IN TURKEY BETWEEN 1996-2014 YEARS: A CONTENT ANALYSIS
}

\author{
Assist. Prof. Dr. Veysel DEMIRER \\ Faculty of Education, Suleyman Demirel University \\ Isparta, TURKEY \\ Cagdas ERBAS \\ Ministry of Education, Ankara, Turkey
}

\section{ABSTRACT}

This study aims to review studies on virtual learning environments in Turkey through the content analysis method. 63 studies consisting of thesis, articles and proceedings published in Turkish and English between 1996-2014 years were analyzed. It was observed that "Second Life" was mostly preferred as the virtual learning environment. Literature review and quantitative research methods were mostly preferred in the studies respectively. Most of these studies used surveys to collect the data and sample size in most studies was between 31-100 participants. Mostly, participants were undergraduate students, and purposive and convenience sampling method were preferred in the studies. The data was mostly analyzed using quantitative descriptive analysis method. The most studied variable was academic achievement and the least one was the cognitive load. The studies yielded varying results owning to their study purposes and showed that virtual learning environments fostered student academic success, diminished the cognitive load by concretizing the concepts and ensured social and collaborative learning. The findings of this study might guide researchers aiming to employ virtual learning environments in their educational studies.

Keywords: Virtual learning environments, research trends, content analysis.

\section{INTRODUCTION}

Education involves a process of changing behaviors through teaching intended behaviors to the individuals. Teaching and learning processes help this intended progress gain. People intentionally convey their knowledge to next generations. Schools and other educational environments are organized to achieve this learning process. From this point of view, learning is driven by the influence and support of these specially organized environments. The structure of learning environments has undergone various transformations by varying educational paradigms to date. The constructivist approach has also changed individuals' roles and learning environments. Today, people learn in collaborative environments under the guidance of teachers (Murugaiah, Atan, Samsudin, \& Idrus, 2004); however, permanence of learning is still a major problem. Considering that more efficient learning environments would yield more permanent learning, new learning environments are structured in line with varying approaches and evolving technological trends.

Evolving technology has induced variations in technologies employed in educational settings over the time. Thus, computer and Internet technologies have been incorporated into educational settings as electronic information sources. Development of computer and Web 2.0 Internet technologies have led to the birth of a new educational environments. This new educational setting was called "virtual learning" or "virtual learning environment". 
Indeed, virtual learning environments were launched with learning machines in 60 s and appeared as an extension of computer-aided learning tools in 70 s and 80 s (Atici, 2007). In particular, Web 2.0 technologies varied and enhanced the usability of virtual environments. Virtual learning environments are described as electronic environments capable of providing any kind of interaction between instructors and students including online learning (Berry, 2005). Atici (2007) defined the virtual learning environment as an educational environment that uses computer and Internet technology supporting students' learning process and experiences.

The constructivist approach shifting the status of students as passive receivers to an active participant role in learning environments has been used since 90s (Jonassen, 1999; Marshall, 1996; Wilson, 1996). In the constructivist approach, students learn the target subject by experiencing, discussing, discovering and deducing as much as possible. The environments should be dynamic and interactive allowing new ideas to realize functions of the constructivist approach in the learning environments (Roussou, 2004), which is today supported in virtual learning environments. Researchers conduct various studies to identify whether virtual learning environments meet these needs, and they examine their effects in student's performance. Finally, this study aims to analyze and discuss studies on virtual learning environments in Turkey and seeks to answers to the following questions:

1) What are the virtual learning environments preferred in the studies and how have they evolved over the years?

2) In the studies on virtual learning environments;

a) What were research methods employed?

b) What were data collection tools employed?

3) Regarding the sampling of virtual learning environments;

a) What were the sample sizes employed?

b) What were the sampling status employed?

c) What were the sampling methods employed?

4) What were the data analysis methods employed?

5) What were the variables addressed by these studies?

6) What were the outcomes of these studies?

\section{METHOD}

In the study, content analysis method one of the qualitative research methods was used to analyze the studies on virtual learning environments in Turkey. Content analysis is a textual analyses of a set of data that typically involves comparing, contrasting, and categorizing to classify the data, and to divide it by different identified themes and concepts (Bauer, 2003; Fraenkel \& Wallen, 2000). According to Tavsancil and Aslan (2001), content analysis is a scientific research approach allowing the objective and systematic examination of verbal, written and other materials. Content analysis is a method used to analyze the studies in a particular field and reach at conclusions based on the findings (Buyukozturk et al., 2012).

\section{Sample of the Study}

The sample of this study consists of the articles, proceedings and thesis conducted till the end of the 2014 in Turkey. The sample population of the study is constituted of databases accessible to the Suleyman Demirel University's Information Centre, the Google Scholar and the thesis database of the Council of Higher Education of Turkey.

\section{Data Collection Process}

Review and selection criteria were established to determine the studies to be analyzed in the study. In the study, the keywords "virtual learning" and "virtual learning environment" were used both in Turkish and in English into the SDU's Information Centre, the Google Scholar and the thesis database of the Council of Higher Education to search studies. 
Following the search, a total of 32 articles in 24 different journals, and 13 proceedings in six different conferences were found on virtual learning environments. 16 master thesis and two Ph.D. thesis were found on virtual learning environments in the Council of Higher Education's national thesis database. Finally, 63 studies carried out in Turkey between the years 1996-2014 were reached and analyzed in the scope of the study. Distributions of place and year of the studies are presented in Appendix-A.

Studies addressing the concept of teaching in virtual learning environments were chosen for the analyses. Data obtained from the studies were recorded in the "Publication Classification Form for Virtual Learning Environment" (Appendix-B) developed by authors utilizing the "Publication Classification Form" (Sozbilir, Kutu, \& Yasar, 2012) and the "The Educational Technology Publication Classification Form" (Goktas et al., 2012).

\section{Data Analysis}

During the content analysis process, one faculty member and one MA student worked together. In the process of analysis and interpretation of studies; the stages of naming, developing category, ensuring validity and reliability, calculating frequencies and interpretation were carefully fulfilled. In order to achieve validity and reliability studies were analyzed on the basis of researchers' agreement. Initial disagreements during the content analysis process were discussed and resolved, and then the rest of the studies were analyzed by collaborative work between the authors. Finally, the data were organized according to the research questions. The data obtained from the content analysis were analyzed by means of the descriptive statistics (percentage, frequency, etc.). The results were organized, classified and presented in tables and charts, and findings were interpreted.

\section{FINDINGS}

The results revealed that the first study on virtual learning environments in Turkey was published in 1996. Therefore, articles, proceedings and theses published between 1996 and 2014 were analyzed in this study. Number of studies analyzed within the scope of the research is 63. Majority of the studies were published in Turkish $(f=51)$ and a small amount of the studies were published in English $(f=12)$. Literature review studies and only development of virtual environment studies were not included in the content analysis.

\section{Virtual Learning Environments Selected in the Studies}

The analysis of the studies revealed that mostly preferred virtual environments were "Second Life" and "Active Worlds". It was further observed that "Opensim", "Quest Atlantis", "Fuvle", "Cubix Editor", "Celestia", "Stellarium" and "Solar Model" represented other virtual environments in the studies. Also, virtual learning environments for educational practice were developed in some studies (Kosaner, 2007; Tuzun \& Ozdinc, 2010). The analysis revealed that the researchers did not utilize virtual learning environments in their studies before 2005. It was observed that the studies till 2005 were mostly literature reviews to create theoretical base for the field. Table 1 shows that studies on virtual learning environments display a progressive increase over the recent years. Although 63 studies were reviewed, only 43 studies were analyzed because some studies were used literature review method. Table 1 shows 51 virtual environments because some of the studies had more than one virtual learning environments. 
Table: 1

Distribution of the preferred virtual environments by year

\begin{tabular}{|c|c|c|c|c|c|c|c|c|c|c|c|}
\hline Virtual Environment & 2005 & 2006 & 2007 & 2008 & 2009 & 2010 & 2011 & 2012 & 2013 & 2014 & Total \\
\hline Second Life & & & & 1 & 1 & & 5 & 7 & 1 & 3 & 18 \\
\hline Active Worlds & & & & & 1 & 3 & & & & & 4 \\
\hline Moodle & & & & & 1 & & 1 & & 2 & & 4 \\
\hline Opensim & & & & & & & & 1 & 1 & & 2 \\
\hline Celestia & & & & & & & & & 2 & & 2 \\
\hline Stellarium & & & & & & & & & 2 & & 2 \\
\hline Solar Model & & & & & & & & & 2 & & 2 \\
\hline Web Quest & & & & 1 & & & & & & 1 & 2 \\
\hline VLE Development & & & 1 & & & 1 & & & & & 2 \\
\hline Quest Atlantis & & 1 & & & & & & & & & 1 \\
\hline Fuvle & & & 1 & & & & & & & & 1 \\
\hline Cubix Editor & & & & & & & & 1 & & & 1 \\
\hline X3D & 1 & & & & & & & & & & 1 \\
\hline True Vision 3D & & & & & & & 1 & & & & 1 \\
\hline Groove Virtual Office & & & 1 & & & & & & & & 1 \\
\hline EFL/ESL & & & & & & & 1 & & & & 1 \\
\hline Other LMS & & & & & 1 & & & 2 & 3 & & 6 \\
\hline Total & 1 & 1 & 2 & 2 & 4 & 4 & 8 & 12 & 13 & 4 & 51 \\
\hline
\end{tabular}

Research Methods and Data Collection Tools

Figure 1 shows the distribution of research methods in the studies on virtual learning environments by the publication year. It was observed that the literature review method was mostly used in the studies and then quantitative, qualitative and mixed studies were used respectively. It was further observed that the literature review method was used in 20 studies, the quantitative research method was used in 16 studies, the qualitative research method was used in $\mathbf{1 6}$ studies and the mixed research method was used in $\mathbf{1 0}$ studies. Furthermore, virtual learning environments were developed in two studies (Kosaner, 2007; Tuzun \& Ozdinc, 2010).

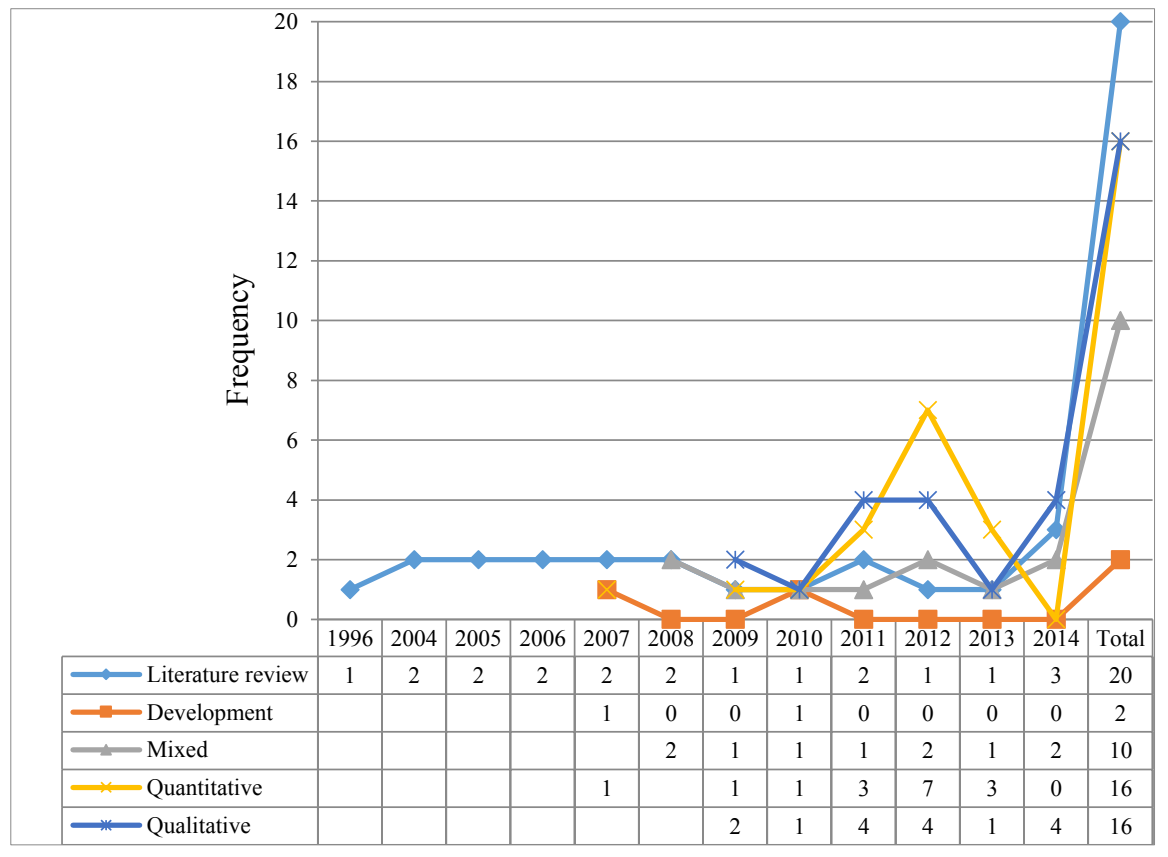

Figure: 1

Distribution of methodologies used in the studies by year 
Data collection tools used in the studies on virtual learning environments are presented in Figure 2. As the data collection tool, "Scales" (35.41\%), "Interviews" $(18.75 \%)$, "Questionnaires" (17.71\%), "Observations" (11.46\%), "Achievement Tests" (8.33\%) and "Diaries (4.17\%)" were used in the studies. In addition, other data collection instruments (1.04\%) were used such as "Cognitive Load Measurement", "Word Measurement", "Eye Tracking" and "Portfolio". Also, it was found that data collection tools were used only in 41 studies. Figure 2 shows 96 tools as some of the studies used a few types of data collection tools in the same study.

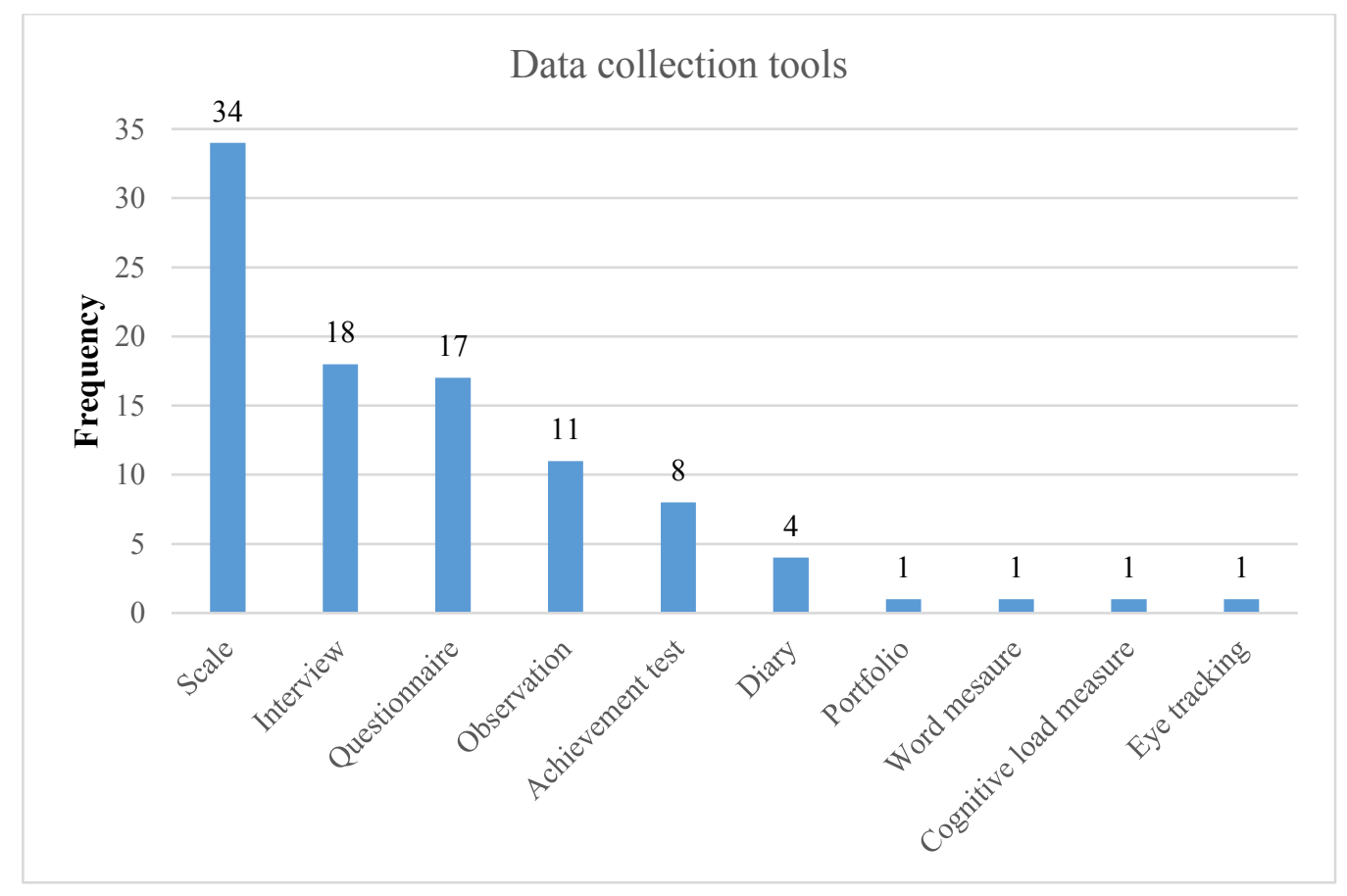

Figure: 2

Distribution of the data collection tools

Table 2 shows detailed distributions for data collection tools of the studies. In majority of the studies, it was seen that scales $(f=38)$ were preferred as the data collection tool. Thus, the most preferred type of scale were likert-type $(f=35)$. Questionnaires $(f=19)$ and interviews $(f=18)$ used more often compared to the others. The results showed that Likerttype questionnaires $(f=13)$ were preferred more than open-ended $(f=3)$ and multiplechoice questionnaires $(f=3)$. Semi-structured interviews $(f=13)$ were found to be the most common tool used in the interview studies. Furthermore, it was seen that the observation tools $(f=11)$ and the achievement tests $(f=7)$ were other data collection instruments used in the studies. The fNIR cognitive load measuring device, word count and recording device and portfolios were used as the alternative data collection tools. Although Figure 2 shows a total of $\mathbf{9 6}$ data collection tools in the studies, detailed distributions for data collection tools reveal 97 tools because one of the studies included both multiple-choice questions and Likert-type questions. 
Table: 2

Detailed distribution of the data collection tools

\begin{tabular}{llll}
\hline Detailed distribution of the data collection tools & $f$ & $\%$ \\
\hline Observation & Semi-structured & 9 & 9.3 \\
& Other & 2 & 2.1 \\
Interview & Structured & 1 & 1.0 \\
& Semi-structured & 13 & 13.4 \\
& Other & 4 & 4.1 \\
Achievement test & Multiple-Choice & 7 & 7.2 \\
Scale & Multiple-Choice & 3 & 3.1 \\
& Likert-type & 35 & 36.1 \\
Questionnaire & Open-ended & 3 & 3.1 \\
& Multiple-Choice & 3 & 3.1 \\
Alternative tools & Likert-type & 13 & 13.4 \\
& Performance identifier & 2 & 2.1 \\
& Portfolio & 1 & 1.0 \\
\hline Total & Data resources & 1 & 1.0 \\
\hline
\end{tabular}

Sample Sizes, Sample Education Levels and Sample Selection Methods

Table 3 shows the distribution of the 41 studies with sample details. It is seen that the most preferred sampling ranges are "31-100" "0-30", "101-300" and "301 and above" respectively.

Table: 3

Distribution of the sample size

\begin{tabular}{lll}
\hline Sample size & $\boldsymbol{f}$ & $\%$ \\
\hline $0-30$ & 15 & 36.6 \\
$31-100$ & 19 & 46.4 \\
$101-300$ & 6 & 14.6 \\
$301+$ & 1 & 2.4 \\
\hline Total & 41 & 100 \\
\hline
\end{tabular}

The distribution of the education levels preferred in $\mathbf{4 0}$ studies are given in Table 4. As seen in Table 4, mostly undergraduate students $(70 \%)$ were chosen as sample groups in the studies. However, primary and high school students and post-graduate students were preferred least often as sample groups.

Table: 4

Distribution of sample level

\begin{tabular}{lll}
\hline Sample education level & $\boldsymbol{f}$ & $\%$ \\
\hline Primary School & 6 & 15 \\
High School & 3 & 7.5 \\
Undergraduate & 28 & 70 \\
Postgraduate & 3 & 7.5 \\
\hline Total & 40 & 100 \\
\hline
\end{tabular}

In the study, 42 studies with sampling method details were analyzed and details are given in Table 5. The most common sample selection methods were the purposive $(52.4 \%)$ and convenience $(42.8 \%)$ sampling. However, random sampling $(4.8 \%)$ were preferred least often as sample selection method in the studies. 
Table: 5

Distribution of the sample selection methods

\begin{tabular}{lll}
\hline Sample selection methods & $\boldsymbol{f}$ & $\%$ \\
\hline Purposive & 22 & 52.4 \\
Convenience & 18 & 42.8 \\
Random & 2 & 4.8 \\
\hline Total & 42 & 100 \\
\hline
\end{tabular}

\section{Data Analysis Methods}

44 studies that provide information on the data analysis method were analyzed. Table 6 shows the distribution of the data analysis methods. Qualitative data analysis method $(37.7 \%)$ was the most common data analysis method. Besides the qualitative data analysis method, quantitative descriptive $(32.8 \%)$ and quantitative inferential $(29.5 \%)$ data analysis methods were also used in the studies. Although 44 studies included data analysis methods, the total number of data analysis methods in Table 6 is 61 because some of the studies used data analysis methods more than one.

Table: 6

Distribution of the data analysis methods

\begin{tabular}{lll}
\hline Data analysis method & $\boldsymbol{f}$ & $\%$ \\
\hline Qualitative & 23 & 37.7 \\
Quantitative Descriptive & 20 & 32.8 \\
Quantitative Inferential & 18 & 29.5 \\
\hline Total & 61 & 100 \\
\hline
\end{tabular}

Table 7 shows the detailed distribution of the data analysis methods. The quantitative inferential analysis method $(f=25)$ was the most common data analysis method and ANOVA $(f=7)$ was the most preferred analysis technique among quantitative inferential data analysis methods. The qualitative content analysis $(f=16)$ method was preferred more than the qualitative descriptive analysis $(f=7)$ method. It was also seen that quantitative descriptive data analysis method $(f=18)$ was used less than quantitative inferential and qualitative analysis methods. It was further observed that means and standard deviations $(f=14)$ were used more than the frequencies/percentages/tables $(f=4)$ in quantitative descriptive analyses.

Table: 7

Detailed distributions of the data analysis methods

\begin{tabular}{llll}
\hline Detailed distributions of the data analysis methods & $\boldsymbol{f}$ & $\%$ \\
\hline Quantitative Descriptive & Frequency/Percentage/Table & 4 & 6.2 \\
& Mean/Standard Deviation & 14 & 21.5 \\
Quantitative Inferential & Correlation & 4 & 6.2 \\
& t- test & 5 & 7.7 \\
& ANOVA & 7 & 10.8 \\
& ANCOVA & 5 & 7.7 \\
& MANOVA & 1 & 1.5 \\
& Factor Analyses & 1 & 1.5 \\
& Non-parametric & 2 & 3.1 \\
Qualitative & Content analysis & 16 & 24.6 \\
& Descriptive Analyses & 7 & 9.2 \\
\hline Total & & 65 & 100 \\
\hline
\end{tabular}


Variable Types Explored in the Studies

In the study, 40 studies examining the influence of virtual environments on one or more variables for educational purposes were investigated. Table 8 shows the distribution of the variables studied in the studies. The most common studied variable was usability $(27.5 \%)$ than academic achievement, skill development, motivation, presence, attitude, efficacy, cognitive load and spatial thinking variables respectively.

Table: 8

Types of variables

\begin{tabular}{lll}
\hline Variables & $\boldsymbol{f}$ & $\%$ \\
\hline Usability & 14 & 27.5 \\
Academic achievement & 9 & 17.6 \\
Skill development & 8 & 15.7 \\
Motivation & 7 & 13.7 \\
Presence & 5 & 9.8 \\
Attitude & 4 & 7.8 \\
Efficacy & 2 & 3.9 \\
Cognitive load & 1 & 2.0 \\
Spatial thinking & 1 & 2.0 \\
\hline Total & 51 & 100 \\
\hline
\end{tabular}

Results of the Studies Conducted in Virtual Learning Environments

The studies showed that usability of the virtual learning environments are important to employ these environments for educational purposes. It was also indicated that virtual learning environments did not significantly have influence on academic success in some studies (Aslan, 2012; Esgin, Pamukcu, \& Ergul, 2012) while other studies had positive significant influence on academic success. It was further concluded that the other variables addressed in the studies such as skill development, motivation, presence, attitude and efficacy were generally influenced significantly in virtual learning environments. Also, it was observed in one study learning and teaching processes in virtual learning environments generally decreased the cognitive load levels of participants (Cansiz, 2012). In addition, experimental studies showed that it was needed less time for activities in virtual learning environments compared to other learning environments (Sengel \& Ozden, 2010).

\section{DISCUSSION AND CONCLUSION}

In this study, the studies conducted on virtual learning environments in Turkey were explored through the content analysis method. When the literature was considered, two content analysis studies were found about virtual environments (Kim, Lee, \& Thomas, 2012; Tokel \& Karatas, 2014). The outcomes of these global studies are consistent with the outcomes of studies in Turkey. Second Life appears as the most preferred virtual environment used in the studies in Turkey. Similarly, Second Life appears as the most common virtual environment in the world (Kim et al., 2012; Tokel \& Karatas, 2014). In addition, consistent with the worldwide studies, Active Worlds, Opensim, Celestia, Stellarium, and Solar Model are used as the common virtual environments respectively. Furthermore, it was observed that specific virtual environments were developed in some studies conducted in Turkey (Kosaner, 2007; Tuzun \& Ozdinc, 2010).

The literature shows that the studies on virtual learning environments around the world has increased obviously starting from 2008 (Kim et al., 2012; Tokel \& Karatas, 2014). In Turkey, a significant increase in the number of studies on virtual learning environments has been observed since 2011. Studies both in Turkey and worldwide are generally literature reviews. Also, the analysis of the studies on virtual learning environments shows that number of quantitative and qualitative researches is close to each other in Turkey. While some of the studies reveal that quantitative and qualitative research methods are employed 
at similar rates in content analysis studies conducted in Turkey on different subjects (Tatar, Kagızmanlı, \& Akkaya, 2013), there are also studies indicating that quantitative research methods are more common than qualitative research methods (Ciltas, Guler, \& Sozbilir, 2012; Goksu, Ozcan, Cakir, \& Goktas, 2014; Selcuk, Palanci, Kandemir, \& Dundar, 2014). Besides literature reviews, quantitative and quantitative methods employed in researches, the mixed research method is used and also development works are implemented to build a virtual learning environment in this field.

It is observed scales are the most common data collection tool, and mostly likert-type scales are preferred. Similarly, the study of Selcuk and his colleagues (2014) indicates that most common data collection tools employed in Turkey are the scales measuring perception, attitude, and other variables. On the other hand, some studies shows that the data collection tool that is mostly preferred is questionnaires (Ciltas et al., 2012; Goksu et al., 2014). In addition, studies on virtual learning environments in Turkey further show that interviews, questionnaires, observations and achievement tests are used as data collection tools respectively besides scales.

The results of content analysis also show that the most common sample size is the $31-100$ range including undergraduate students, which is consistent with the findings of another content analysis studies (Ciltas et al., 2012; Tatar et al., 2013). It could be argued that the selected research method is effective in determining the sample size. It is observed in the studies on virtual learning environments in Turkey that some sampling criterion are defined prior to the sample selection, and mostly purposive sampling method is used. Furthermore, the key reason to select undergraduate students as a sample is that the academicians access easier to undergraduate students to conduct their studies.

In the study, it is seen that the most common studied variable in virtual learning environments is usability than academic success, skill development, motivation, presence, attitude, efficacy, cognitive load and spatial thinking respectively. The diversity of the variables is generally consistent with studies conducted in the field of education. The findings of the studies show that activities implemented in virtual learning environments have positive influence on the variables examined in the studies. On the other hand, the studies on the usability reveal that virtual learning environments may be used in teaching and learning processes.

\section{SUGGESTIONS}

This results of the study seems important to put forward the current situation by examining the studies on virtual learning environments conducted in Turkey. The opinion is that the findings of this study may guide researchers aiming to employ virtual learning environments. The main limitation of the study is that virtual learning environments used in the studies show different characteristics. In conclusion, some suggestions may be developed for future studies based on the results.

It is seen that single virtual environment is generally used and its impact on variables is examined in the studies. Therefore, two or more virtual environments may be used and their effects on variables may be compared. Also, the effects on different variables of virtual learning environment may be analyzed. Furthermore, researchers may conduct new studies to discover the influence of virtual learning environments on permanent learning. Moreover, some scales may be developed to use in the field studies and they may be used to obtain more reliable results about the effects of the virtual learning environments on several variables. Finally, longitudinal studies may be conducted to explore the long-term influences of virtual learning environments on wide samples. 


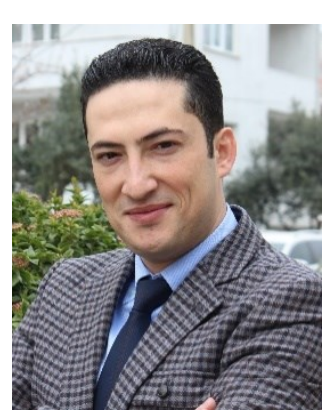

Dr. Veysel DEMIRER has a PhD degree in Curriculum and Instruction. Currently, he is an assistant professor in Faculty of Education, Department of Computer Education and Instructional Technology, Suleyman Demirel University where he lectures on educational science, educational technology, and technology integration and teacher education. He specializes in teacher training, educational technology, and psycho-social aspects of technology use. In these areas of expertise, he has published articles, books, book chapters and given international presentations. He is an active member of the Association Turkish Information \& Communication Technologies Educators. He currently lives in Isparta, Turkey with his wife and two daughters, where he enjoys running, tracking, travelling and driving.

Assist. Prof. Dr. Veysel DEMIRER, Suleyman Demirel University, Faculty of Education, Department of Computer Education \& Instructional Technology, Isparta, 32260, TURKEY

Phone: +902462114583 Fax: +902462114505

e-Mail: veyseldemirer@gmail.com

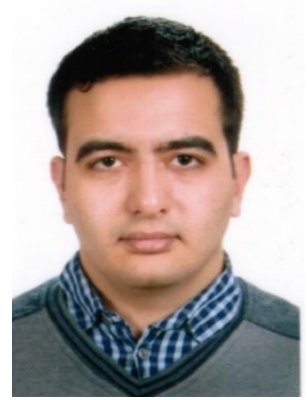

Cagdas ERBAS has a Ma. Sc. degree in Computer Education and Instructional Technology at Suleyman Demirel University. Currently, he has a sponsorship from Republic of Turkey, Ministry of Education. He specializes in educational technology. In these areas of expertise, he has published articles, book chapters and given international presentations. He currently lives in Austin Texas in the US, where he is studying English.

Cagdas ERBAS,

Ministry of Education, Ankara, Turkey

Phone: +905053768391

e-Mail: cagerbas@gmail.com

\section{REFERENCES}

Aslan, A. (2012). Effect of virtual learning environments, appropriate with learning styles, on student success and opinions (Unpublished master's dissertation). Firat University, Elazig.

Atici, B. (2007). The efficiency of virtual learning environments based on social knowledge construction on learners' achievement and attitudes. Education \& Science, 32(143), 41-53.

Bauer, M. W. (2003). Classical content analysis: a review. In M. W. Bauer, \& G. Gaskell (Eds.), Qualitative Researching with Text, Image and Sound (pp. 131-151). London: Sage Publication.

Berry, M. (2005). A virtual learning environment in primary education. Retrieved May 27, 2014, from http://www.worldecitizens.net/ftp/Primary\%20VLE.pdf 
Buyukozturk, S., Kilic-Cakmak, E., Akgun, O. E., Karadeniz, S., \& Demirel, F. (2012). Scientific research methods. Ankara: Pegem Akademi.

Cansiz, Y. (2012). Effects of way finding affordances on usability of virtual world environments in terms of users' satisfaction, performance, and mental workload: Examination by eye-tracking and fNIR device (Unpublished master's dissertation). Middle East Technical University, Ankara.

Ciltas, A., Guler, G., \& Sozbilir, M. (2012). Mathematics education research in Turkey: a content analysis study. Educational Sciences: Theory \& Practice (ESTP), 12(1), 565-580.

Esgin, E., Pamukcu, B. S., \& Ergul, P. (2012). The effects of 3-d online social environments in educational use on student success and motivation: Secondlife case. e-Journal of New World Sciences Academy-Education Sciences, $7(1), 476-484$.

Fraenkel, J. R., \& Wallen, N. (2000). How to design and evaluate research in education (4th ed.). NY: McGraw-Hill.

Goktas, Y., Kucuk, S., Aydemir, M., Telli, E., Arpacik, O., Yildirim, G., \& Reisoglu, I. (2012). Educational technology research trends in Turkey: a content analysis of the 20002009 decade. Educational Sciences: Theory \& Practice, 12(1), 177-199.

Goksu, I., Ozcan, K. V., Cakir, R., \& Goktas, Y. (2014). Studies related to instructional design models in Turkey. Elementary Education Online, 13(2), 694-709.

Jonassen, D. H. (1999). Designing constructivist learning environments. In C. M. Reigeluth (Ed.), Instructional-design theories and models (pp. 215-239). Mahwah, NJ: Lawrence Erlbaum.

Kim, S. H., Lee, J., \& Thomas, M. K. (2012). Between purpose and method: a review of educational research on 3D virtual worlds. Journal for Virtual Worlds Research, 5(1), 1-18.

Kosaner, O. (2007). Active learning: development of a virtual learning environment for PBL sessions. In E. Alıcl (Ed.) Proceedings of the 4th Active Education Conference (pp. 4552). Izmir: Dokuz Eylul University. Retrieved from 15 June, 2014, from http://kisi.deu.edu.tr/ozgun.kosaner/dosyalar/AEK 2007 Sanal-PDO.pdf.

Marshall, H. H. (1996). Implications of differentiating and understanding constructivist approaches. Educational Psychologist, 3/4(31), 235-240.

Murugaiah, P., Atan, H., Samsudin, D. S., \& Idrus, R. M. (2004, August). The web-based learning environment: a comparative study between the constructivist and contentbased approaches. In Advanced Learning Technologies, 2004. Proceedings. IEEE International Conference on (pp. 810-812). IEEE.

Roussou, M. (2004). Learning by doing and learning through play: an exploration of interactivity in virtual environments for children. ACM Computers in Entertainment, 1(2), 1-23. 
Selcuk, Z., Palanci, M., Kandemir, M., \& Dundar, H. (2014). Tendencies of the researches published in Education and Science journal: content analysis. Education \& Science, 39(173), 428-449.

Sozbilir, M., Kutu, H., \& Yasar, M. D. (2012). Science education research in Turkey: A content analysis of selected features of papers published. In J. Dillon \& D. Jorde (Eds). The World of Science Education: Handbook of Research in Europe (pp.341-374). Rotterdam: Sense Publishers.

Sengel, E., \& Ozden, M. Y. (2010). The effects of computer simulated experiments on high school students' understanding of the displacement and velocity concepts. Eurasian Journal of Educational Research, 39, 191-211.

Tatar, E., Kagızmanlı, T. B., \& Akkaya, A. (2013). Content analysis of the researches on technology-assisted mathematics instruction in Turkey. Buca Faculty of Education Journal, 35, 33-50.

Tavsancıl, E., \& Aslan, E. (2001). Content analysis and application examples. İstanbul: Epsilon.

Tokel, S. T., \& Karatas, E. C. (2014). Three-dimensional virtual worlds: research trends and future directions. Mersin University Journal of the Faculty of Education, 10(1), 1-12.

Tuzun, H., \& Ozdinc, F. (2010). Development of 3d virtual university orientation environment. Proceedings of the XII. Akademik Bilisim Conference, Mugla, Turkey, 523-527. Retrieved 28 May, 2014 from, http://ab.org.tr/ab10/kitap/tuzun_ozdinc_AB10.pdf

Wilson, B. G. (1996). What is a constructivist learning environment? In B. Wilson (Ed.), Constructivist learning environments: Case studies in instructional design (pp. 3-8). Englewood Cliffs, NJ: Educational Technology Publications. 


\section{APPENDIXES}

\section{A. Distribution of the studies by year}

\begin{tabular}{|c|c|c|c|c|c|c|c|c|c|c|c|c|c|}
\hline Source & $\begin{array}{l}\circ \\
\text { و } \\
\end{array}$ & ষ্ণ & 옹 & ஜ & 옹 & 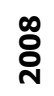 & $\begin{array}{l}\text { 용 } \\
\text { 옹 }\end{array}$ & $\begin{array}{l}\text { 움 } \\
\text { 유 }\end{array}$ & 공 & 공 & 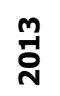 & 离 & $\begin{array}{l}\bar{\pi} \\
\text { o } \\
\text { - }\end{array}$ \\
\hline Council of Higher Education's National Thesis Database & & & & & & 1 & 1 & 1 & 3 & 7 & 3 & 2 & $\begin{array}{l}1 \\
8\end{array}$ \\
\hline Akademik Bilisim Conference & & & 1 & & 1 & & 2 & $\mathbf{1}$ & 1 & & 1 & & 7 \\
\hline $\begin{array}{l}\text { International Computer \& Instructional Technologies } \\
\text { Symposium }\end{array}$ & & & & & & & & 1 & 2 & & & & 3 \\
\hline Turkish Online Journal of Educational Technology & & 2 & 1 & & & & & & & & & & 3 \\
\hline Education \& Science & & & & & 1 & & & & & & & 1 & 2 \\
\hline Eurasian Journal of Educational Research & & & & & & & & $\mathbf{1}$ & & & & & 1 \\
\hline H. U. Journal of Education & & & & 1 & & & & & 1 & & & & 2 \\
\hline Educational Sciences: Theory \& Practice & & & & & & & & & & 2 & & & 2 \\
\hline Mersin University Journal of the Faculty of Education & & & & & & & & & & & 1 & 1 & 2 \\
\hline Procedia - Social and Behavioral Sciences & & & & & & & 1 & & & & & 1 & 2 \\
\hline Turkish Librarianship & 1 & & & & & & & & & 1 & & & 2 \\
\hline $\begin{array}{l}\text { Journal of the Abant İzzet Baysal University Faculty of } \\
\text { Education }\end{array}$ & & & & & & & & & & & & 1 & 1 \\
\hline Journal of Kırsehir Education Faculty & & & & & & & & & 1 & & & & 1 \\
\hline Active Education Conference & & & & & 1 & & & & & & & & 1 \\
\hline $\begin{array}{l}\text { Ankara University Journal of Faculty of Educational } \\
\text { Sciences }\end{array}$ & & & & & & 1 & & & & & & & 1 \\
\hline Australasian Journal of Educational Technology & & & & & & & & & & & 1 & & 1 \\
\hline International Journal of Informatics Technologies & & & & & & 1 & & & & & & & 1 \\
\hline Computers \& Education & & & & & & & & & 1 & & & & 1 \\
\hline The Journal of Cumhuriyet University Faculty of Dentistry & & & & 1 & & & & & & & & & 1 \\
\hline Journal of the Duzce University Institute of Health Sciences & & & & & & & & & & & & 1 & 1 \\
\hline International Congress of Educational Research & & & & & & & & & & 1 & & & 1 \\
\hline Journal of Qualitative Research in Education & & & & & & & & & & & & 1 & 1 \\
\hline e-Journal of New World Sciences Academy & & & & & & & & & & 1 & & & 1 \\
\hline Electronic Journal of Social Sciences & & & & & 1 & & & & & & & & 1 \\
\hline Journal of the Hasan Ali Yucel Faculty of Education & & & & & & & & & & 1 & & & 1 \\
\hline Internet Conference & & & & & & & & & $\mathbf{1}$ & & & & 1 \\
\hline Marmara Medical Journal & & & & & & & & 1 & & & & & 1 \\
\hline Maths Education Journal & & & & & & & & & & 1 & & & 1 \\
\hline Route Educational and Social Science Journal & & & & & & & & & & & & 1 & 1 \\
\hline Afyon Kocatepe University Journal of the Social Sciences & & & & & & 1 & & & & & & & 1 \\
\hline (2) & 1 & 2 & 2 & 2 & 4 & 4 & 4 & 5 & $\begin{array}{l}\mathbf{1} \\
\mathbf{0}\end{array}$ & $\begin{array}{l}1 \\
4\end{array}$ & 6 & 9 & $\begin{array}{l}6 \\
3\end{array}$ \\
\hline
\end{tabular}


Appendix B. Publication classification form for virtual learning environment

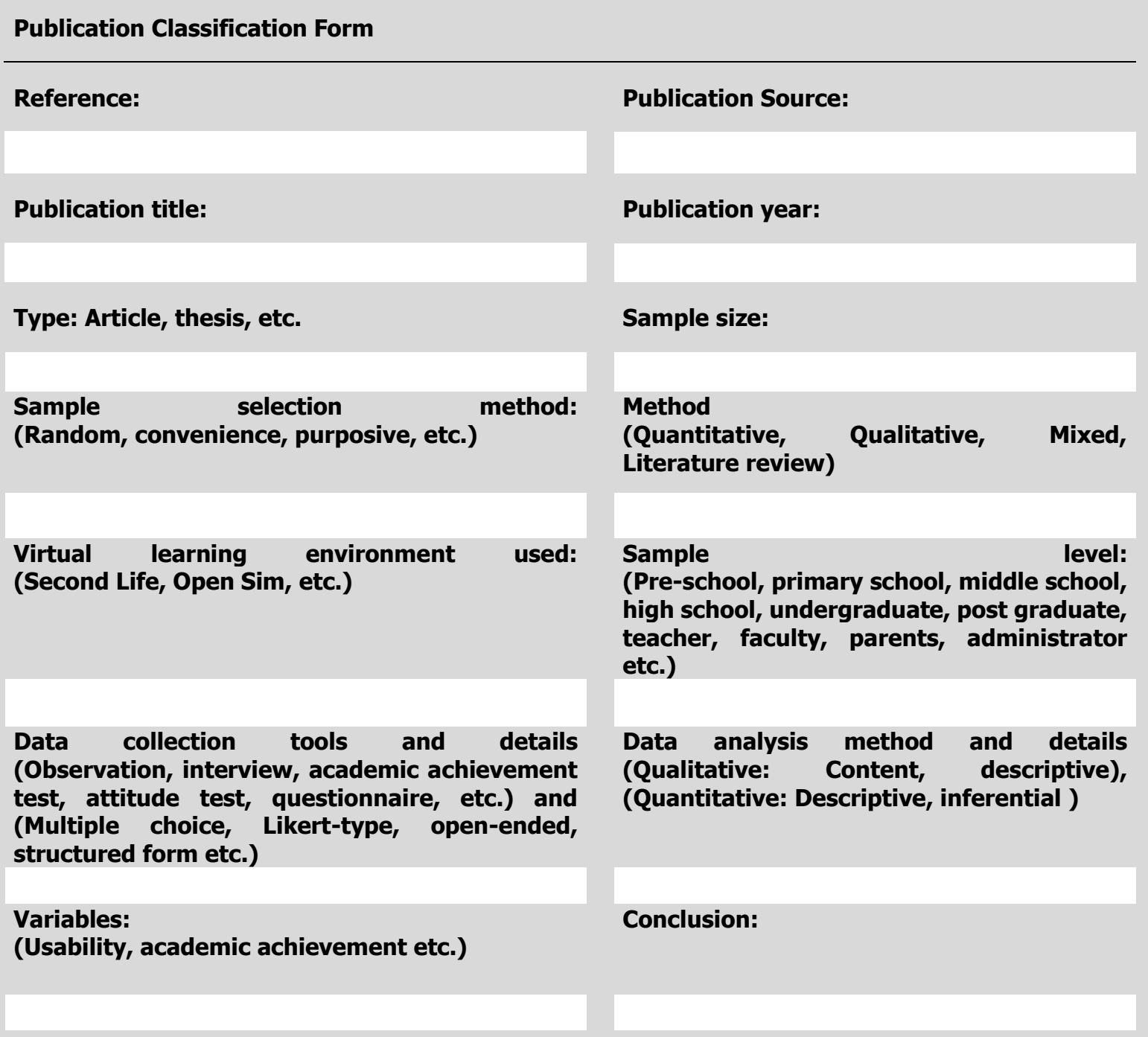

